American Journal of Pharmaceutical Education 2016; 80 (7) Article 127.

\title{
REVIEW
}

\section{Pharmacy Student Learning During Advanced Pharmacy Practice Experiences in Relation to the CAPE 2013 Outcomes}

\author{
Vincent C. Dennis, PharmD, ${ }^{a}$ Dianne W. May, PharmD, ${ }^{\text {b }}$ Tina J. Kanmaz, PharmD, ${ }^{c}$ \\ Shannon L. Reidt, PharmD, MPH, ${ }^{d}$ Michelle L. Serres, PharmD, ${ }^{e}$ Heather D. Edwards, PharmD ${ }^{\mathrm{a}}$ \\ ${ }^{a}$ University of Oklahoma College of Pharmacy, Oklahoma City, Oklahoma \\ ${ }^{\mathrm{b}}$ University of Georgia College of Pharmacy, Athens, Georgia \\ c St. John's University College of Pharmacy and Health Sciences, Queens, New York \\ ${ }^{\mathrm{d}}$ University of Minnesota College of Pharmacy, Minneapolis, Minnesota \\ e The University of Toledo College of Pharmacy and Pharmaceutical Sciences, Toledo, Ohio \\ Submitted July 2, 2015; accepted September 6, 2015; published September 25, 2016.
}

\begin{abstract}
Outcomes from The Center for Advancement of Pharmacy Education (CAPE) are intended to represent the terminal knowledge, skills, and attitudes pharmacy students should possess and have guided delivery of pharmacy education for more than two decades. Advanced pharmacy practice experiences (APPEs) are the endpoint of pharmacy curricula where demonstration and assessment of terminal learning occurs. This review examines published literature in relation to the most recent CAPE outcomes to determine the extent to which they have been addressed during APPEs since 1996. Details related to the APPE focus, intervention(s)/learning setting(s), and assessments are summarized according to the 15 CAPE outcomes. Further, the assessments are categorized according to the level of learning achieved using an available method. Common CAPE outcomes are highlighted, as well as those for which published reports are lacking for APPEs. The range and quality of assessments are discussed and emphasize the need for continuous improvement of scholarly design and assessment.
\end{abstract}

Keywords: experiential education, APPE, CAPE outcomes, assessment, Kirkpatrick's Hierarchy

\section{INTRODUCTION}

The Center for Advancement of Pharmacy Education (CAPE) outcomes have guided pharmacy curriculum design, implementation and assessment since 1992, with the most recent iteration released in $2013 .{ }^{1}$ Since their inception, the CAPE outcomes have been a key resource for colleges and schools, faculty members, and preceptors when considering terminal knowledge, skills, and attitudes pharmacy graduates must possess. The revision process of the CAPE outcomes seeks to identify and include contemporary and emerging issues in pharmacy education so that the pharmacy profession may meet current and future health care needs. The CAPE outcomes are intended to be achievable by the conclusion of a doctor of pharmacy (PharmD) program, and measureable within practice environments. Since the advanced pharmacy practice experience (APPE) component of the curriculum

Corresponding Author: Vincent C. Dennis, Department of Pharmacy, Clinical and Administrative Sciences, University of Oklahoma College of Pharmacy, 1110 N. Stonewall Ave., PO Box 26901, Oklahoma City, OK 73126-0901. Tel: 405271-6484, Ext. 47372. Fax: 405-271-3531. E-mail: VincentDennis@ouhsc.edu is the culmination of a professional program, it represents the final phase in which achievement of CAPE outcomes occur. Further, the American Council for Pharmacy Education (ACPE) chose to adopt, without modification, the CAPE 2013 outcomes as the educational outcomes of focus for the latest revision of its Accreditation Standards for Doctor of Pharmacy Programs. ${ }^{2,3}$ More emphasis is now placed on assessment of student achievement of CAPE outcomes, ${ }^{2}$ which requires thoughtful design and measurement.

Promoting the scholarship of teaching and learning is important for the advancement of academic missions. Experiential education has been capturing representative terminal assessments of curricular outcomes through publications for nearly two decades since conversion to the entry level PharmD program model. The CAPE outcomes have influenced the focus of experiential education during this time frame; however, it is uncertain if literature related to experiential education addresses all of the CAPE outcomes. Experiential education program design, delivery, and assessment provide an important opportunity for terminal assessment of CAPE outcomes. Understanding how extensively 


\section{American Journal of Pharmaceutical Education 2016; 80 (7) Article 127.}

experiential education literature addresses CAPE outcomes may identify gaps and help the academy advance curricular initiatives. Equally important is describing the level at which achievement of educational outcomes has occurred in APPE environments, which can help refine approaches to experiential learning. A method of evaluating the effectiveness of training programs as defined by levels of learning using Kirkpatrick's hierarchy $(\mathrm{KH})$ has been described. ${ }^{4,5}$ This method of evaluating levels of learning has been applied to e-learning in pharmacy education using four general levels [(1) reaction, (2) learning, (3) behavior, and (4) results], and is applicable to experiential education as well. ${ }^{6}$ The primary purposes of this Review are to determine the extent to which published literature involving pharmacy students on APPEs addresses the CAPE outcomes and to describe the level of learning assessments relative to $\mathrm{KH}$.

\section{METHODS}

To identify keywords and Medical Subject Heading (MESH) terms related to our primary purpose, the table of contents of the American Journal of Pharmaceutical Education, Currents in Pharmacy Teaching and Learning, and Annals of Pharmacotherapy were reviewed for the calendar year 2012. These journals were selected to represent those likely to publish scholarly articles related to experiential teaching and learning in pharmacy. A Medline search was also performed from 1996 to 2014 using the term "experiential education and pharmacy." Article titles and abstracts for both introductory search methods were reviewed for relevance, in addition to extracting MESH headings to assist with refining search terminology. By reviewing desirable citations for common search terms, the initial MESH terms of "education, pharmacy" or "students, pharmacy" were grouped with "Experien*. mp" to broadly characterize our initial search strategy. This search strategy was first utilized in OVID for journals indexed in Medline using the time frame of 1996 to December 31, 2014 and subsequently deployed for other search engines including Excerpta Medica Database (EMBASE), Education Resources Information Center (ERIC), and International Pharmaceutical Abstracts (IPA), matching the most closely related search terms within each database for relevant journals. The beginning time frame of 1996 was selected as a time point just prior to implementation of the ACPE entry-level PharmD program standards in 1997, when APPEs were first articulated, to capture early reports that may have addressed terminal outcomes still deemed relevant at the present time. The final databases used were selected to encompass major teaching and learning journals in the health professions. ${ }^{7}$ In addition, the table of contents of the journal Innovations in Pharmacy was reviewed since it was not indexed in any of the available search engines.

Citations retrieved from the search strategy were reviewed for relevance and included if they reported assessment of student learning through APPEs in PharmD programs of US schools of pharmacy. Reports of international APPEs were included only if they originated from a US school of pharmacy. Only noncompensated reports were included, as opposed to those involving paid internship experiences outside the curriculum. For inclusion, an article needed to include data from assessment of learning in relation to the educational activity or intervention. Articles that reported student contributions to patient care such as documentation of clinical interventions but that did not also include assessment of student impact such as acceptance or implementation of interventions were not included. Articles purely descriptive in nature or that reported general findings for competencies or outcomes, but lacked specific assessment information, also were not included in our review.

A minimum of two authors independently reviewed each citation for inclusion and selected up to three CAPE outcomes most closely related to the learning assessed through the respective APPE; discrepancies of categorization were resolved via author consensus. Data extraction for each citation included the type of educational intervention, assessment methods utilized, number/type of students, limitations/other relevant information, and the practice setting (if applicable). Each citation was also reviewed in duplicate for the impact of the educational intervention and assigned one of six levels from KH of learning (Appendix 1). ${ }^{4-6}$ Discrepancies of categorization were again resolved via author consensus.

\section{RESULTS}

Our review and synthesis included 91 published articles. The CAPE outcomes deemed to be the primary focus of each article and the associated $\mathrm{KH}$ assigned are listed in Table 1. ${ }^{8-98}$ Overall, the subdomains of patientcentered care (2.1), learner (1.1), and self-awareness (4.1) were the most commonly addressed primary outcomes for included publications, and these areas occurred in a comparatively equal number of reports. The subdomains of patient advocacy (3.3), leadership (4.2), and innovation/ entrepreneurship (4.3) were not found to be primary outcomes of focus in published literature to date. With regard to $\mathrm{KH}$ level, the approximate distribution was $36 \%$ of reports at level 1 (reaction/participation), 30\% at level 2 (learning), $7 \%$ at level 3 (behavior change), and 27\% at level 4 (results). 


\section{American Journal of Pharmaceutical Education 2016; 80 (7) Article 127.}

Table 1. Categorization of Publications Reporting Student Learning on Advanced Pharmacy Practice Experiences by Primary CAPE Outcome Addressed and Impact of Intervention by Kirkpatrick's Hierarchy Level

\begin{tabular}{|c|c|c|c|c|c|c|c|}
\hline \multirow[b]{2}{*}{ CAPE Outcome $e^{b, c}$} & \multicolumn{7}{|c|}{ Kirkpatrick's Hierarchy ${ }^{\text {a,b }}$} \\
\hline & Articles & Level 1 & Level 2a & Level 2b & Level 3 & Level 4a & Level 4b \\
\hline 1.1 Learner & (16) & $8-12(5)$ & $13-15(3)$ & $16-21(6)$ & $22-23(2)$ & & \\
\hline 2.1 Caregiver & (26) & $24-26(3)$ & $27(1)$ & $28-31(4)$ & & $32-33(2)$ & $34-49(16)$ \\
\hline 2.2 Manager & (3) & $50(1)$ & & & & & $51-52(2)$ \\
\hline 2.3 Promoter & (8) & $53-56(4)$ & & $57-58(2)$ & & & $59-60(2)$ \\
\hline 2.4 Provider & (2) & $61(1)$ & & & & & $62(1)$ \\
\hline 3.1 Problem solver & (2) & & & $63(1)$ & $64(1)$ & & \\
\hline 3.2 Educator & (4) & $65-66(2)$ & & & $67(1)$ & $68(1)$ & \\
\hline 3.4 Collaborator & (1) & $69(1)$ & & & & & \\
\hline 3.5 Includer & (4) & $70-71(2)$ & $72-73(2)$ & & & & \\
\hline 3.6 Communicator & (2) & $74(1)$ & & $75(1)$ & & & \\
\hline 4.1 Self-aware & (21) & $76-88(13)$ & $89-95(7)$ & & & $96(1)$ & \\
\hline 4.4 Professional & (2) & & & & $97-98(2)$ & & \\
\hline Total articles & (91) & (33) & (13) & (14) & (6) & (4) & (21) \\
\hline
\end{tabular}

$\mathrm{CAPE}=$ Center for the Advancement of Pharmacy Education

${ }^{\mathrm{a}}$ Level $1=$ satisfaction or opinions (reaction); $2 \mathrm{a}=$ modification of attitudes/perceptions (learning); $2 \mathrm{~b}=$ change in knowledge or skills (learning); $3=$ change in behavior (behavior); $4 \mathrm{a}=$ change in organizational practice (results); $4 \mathrm{~b}=$ documented improvement in health/well-being of patients (results)

${ }^{\mathrm{b}}$ Data displayed as the reference citation number or range (count)

${ }^{\mathrm{c}}$ Applicable publications were not deemed to be the primary focus for CAPE outcomes 3.3 (advocate), 4.2 (leader), or 4.3 (innovator)

Tables 2-4 represent stratifications of included articles by KH levels 1, 2, and a combination of levels 3 and 4 , respectively. Summary details for articles are organized by CAPE outcome subdomain, APPE knowledge/focus, intervention/learning setting, and assessment method(s) within each of the respective KH level designations. Table 2 includes all articles that used assessment methods consistent with $\mathrm{KH}$ level 1, such as student or faculty-completed surveys post-APPE, the majority of which were not specified as being validated. ${ }^{8-12,24-26,50,53-56,61,65,66,69-71,74,76-88}$ Approximately three-quarters of the articles used studentcompleted surveys as the primary assessment method. Two-thirds of the 15 CAPE outcome subdomains were represented by APPE reports using assessment methods consistent with KH level 1, with self-awareness (4.1) being the most commonly represented subdomain for this level.

Table 3 includes all articles that used assessment methods consistent with $\mathrm{KH}$ levels $2 \mathrm{a}$ (modification of attitudes/perceptions) or $2 \mathrm{~b}$ (modification of knowledge/ skills). ${ }^{13-21,27-31,57,58,63,72,73,75,89-95}$ Survey assessment methods included pre/post-APPE applications and some examples of validated surveys for CAPE subdomain 3.5 (cultural sensitivity). Knowledge and skill assessments included methods such as multiple-choice or written examinations and preceptor-directed performance assessments of students. Only $40 \%$ of the 15 CAPE outcome subdomains were represented by APPE reports using assessment methods consistent with KH level $2 \mathrm{a}$ or $2 \mathrm{~b}$, with learner (1.1) and self-awareness (4.1) being the most commonly represented subdomains for this level.

Table 4 includes all articles that used assessment methods consistent with KH levels 3 (behavior change), $4 \mathrm{a}$ (change in organizational practice), or $4 \mathrm{~b}$ (improvement in patient health/well-being). ${ }^{22,23,32-49,51,52,59,60,62,64,67,68,96-98}$ Nine of 15 CAPE outcomes $(60 \%)$ were represented at these higher $\mathrm{KH}$ levels, and approximately $60 \%$ of the reports were comprised of subdomain 2.1 (patient-centered care). Assessment methods used were consistent with this subdomain and included medication reconciliation, identification of drug-related problems, and acceptance of clinical intervention recommendations, as well as other measures promoting quality and/or costeffectiveness.

Table 5 summarizes the categorization of publications including not only the primary CAPE outcome, but a second and third level of focus, when applicable. This summary shows a broader view of the CAPE outcomes addressed and reveals that the subdomain of communication (3.6) was commonly included at the second or third level of focus, making it the fourth most commonly addressed subdomain behind patient-centered care (2.1), learner (1.1), and self-awareness (4.1). Table 6 organizes the information from Table 5 by date ranges and shows a progressive increase in the number publications per time frame for the majority of the subdomains since 1997, while other subdomains have only been reported more recently. 
American Journal of Pharmaceutical Education 2016; 80 (7) Article 127.

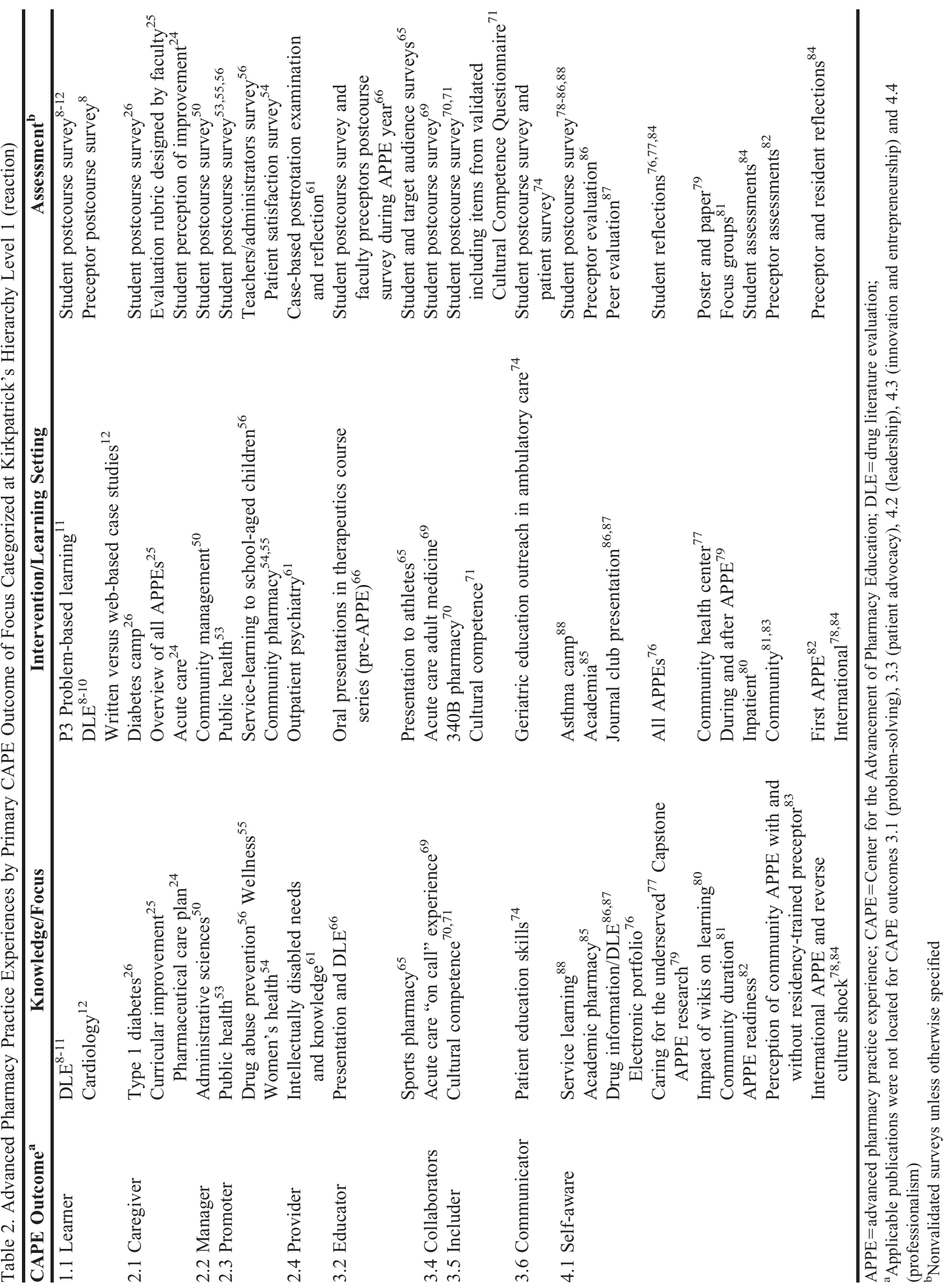


American Journal of Pharmaceutical Education 2016; 80 (7) Article 127.

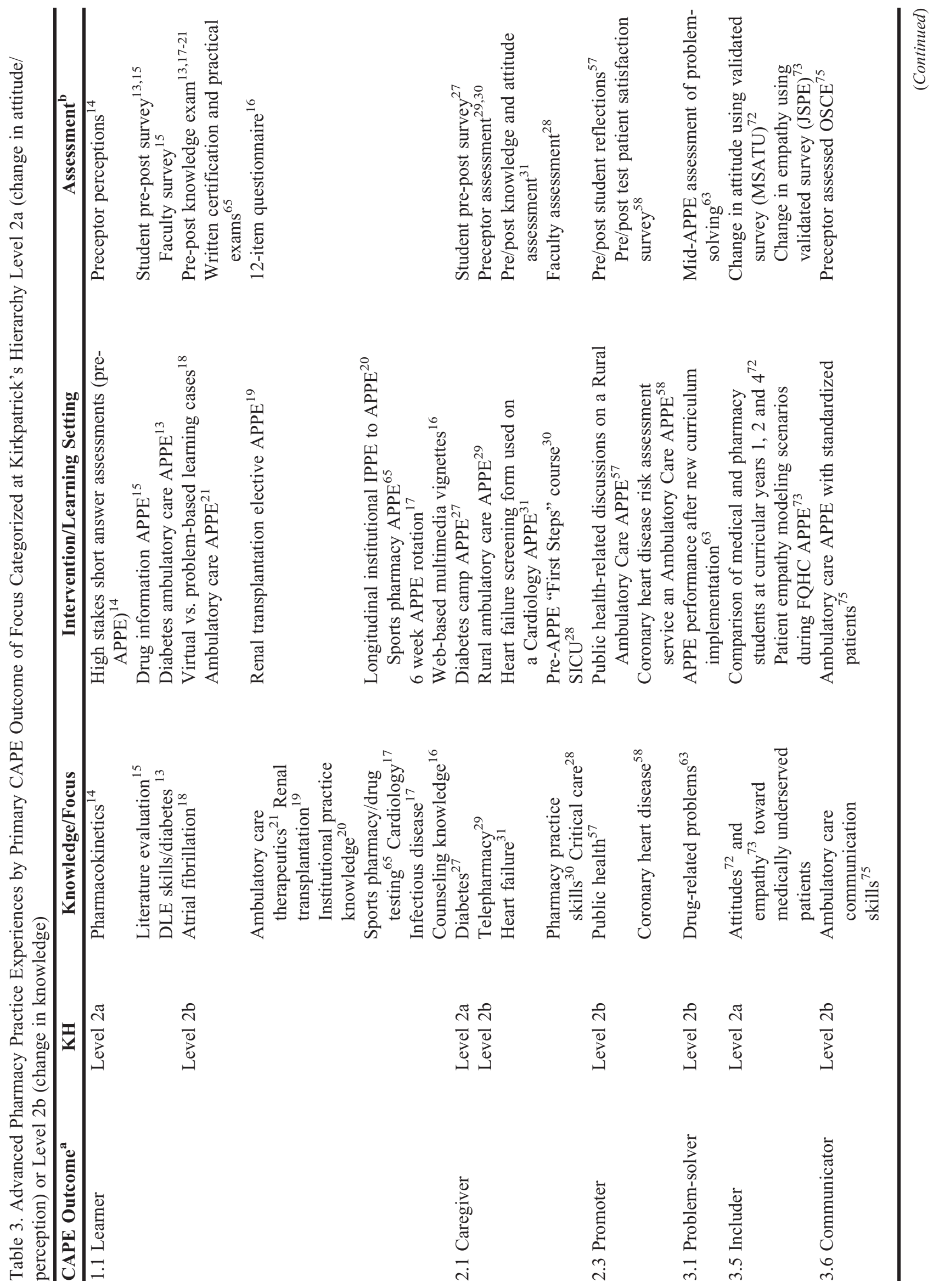


American Journal of Pharmaceutical Education 2016; 80 (7) Article 127.

\section{DISCUSSION}

A primary purpose of this review was to determine the extent and level to which published literature involving pharmacy students on APPEs assesses learning relative to the CAPE outcomes. Several observations from the results are noteworthy. First, faculty members and preceptors reported pharmacy student learning and contributions in areas consistent with the majority of the 15 CAPE outcome subdomains. This is encouraging because the APPE year comprises at least $25 \%$ of the curriculum and represents terminal learning for professional programs. It is also clear that the primary focus for approximately $47 \%$ of the included reports related to the subdomains of either patient-centered care (2.1) or learner (1.1). This finding is not surprising as these two subdomains are inclusive of many fundamental competencies in areas such as knowledge application, literature evaluation, collection/interpretation of evidence, implementation/monitoring of plans, and documentation. Certain CAPE outcome subdomains such as communication (3.6) and educator (3.2) were less likely to be coded as the primary focus but frequently occurred at the second or third level, emphasizing their importance.

While our review provides a useful glimpse at the distribution of CAPE outcomes in published literature, underlying reasons why certain subdomains are underrepresented cannot be specifically determined. Conceivably, assessment methods to capture APPE learning outcomes for some CAPE outcome subdomains (such as leadership) are more challenging or not yet developed, making them less likely to be reported in recent literature. Another consideration is that a general CAPE outcome subdomain such as problem solving (3.1) overlaps with patientcentered care (2.1), making it less likely to be separately identified. The focus of our review was reporting at the APPE level, so some of these outcomes may have been investigated and published at the introductory pharmacy practice experience level and would not have been included. Another important distinction is the evolving nature of the CAPE outcomes and ACPE accreditation standards, which we suspect may influence scholarly reports of student learning outcomes over time (Table 6). For example, $75 \%$ of the publications we reported involving the cultural sensitivity subdomain (3.5) occurred in 2008 or later. When reflecting on ACPE accreditation standards, those adopted in 2006 (effective in 2007) included stronger language for cultural competency within standards for curriculum and professional outcome expectations in comparison to the previous ACPE standards. Population-health management was also emphasized in the ACPE 2007 standards and all publications judged to 
American Journal of Pharmaceutical Education 2016; 80 (7) Article 127.

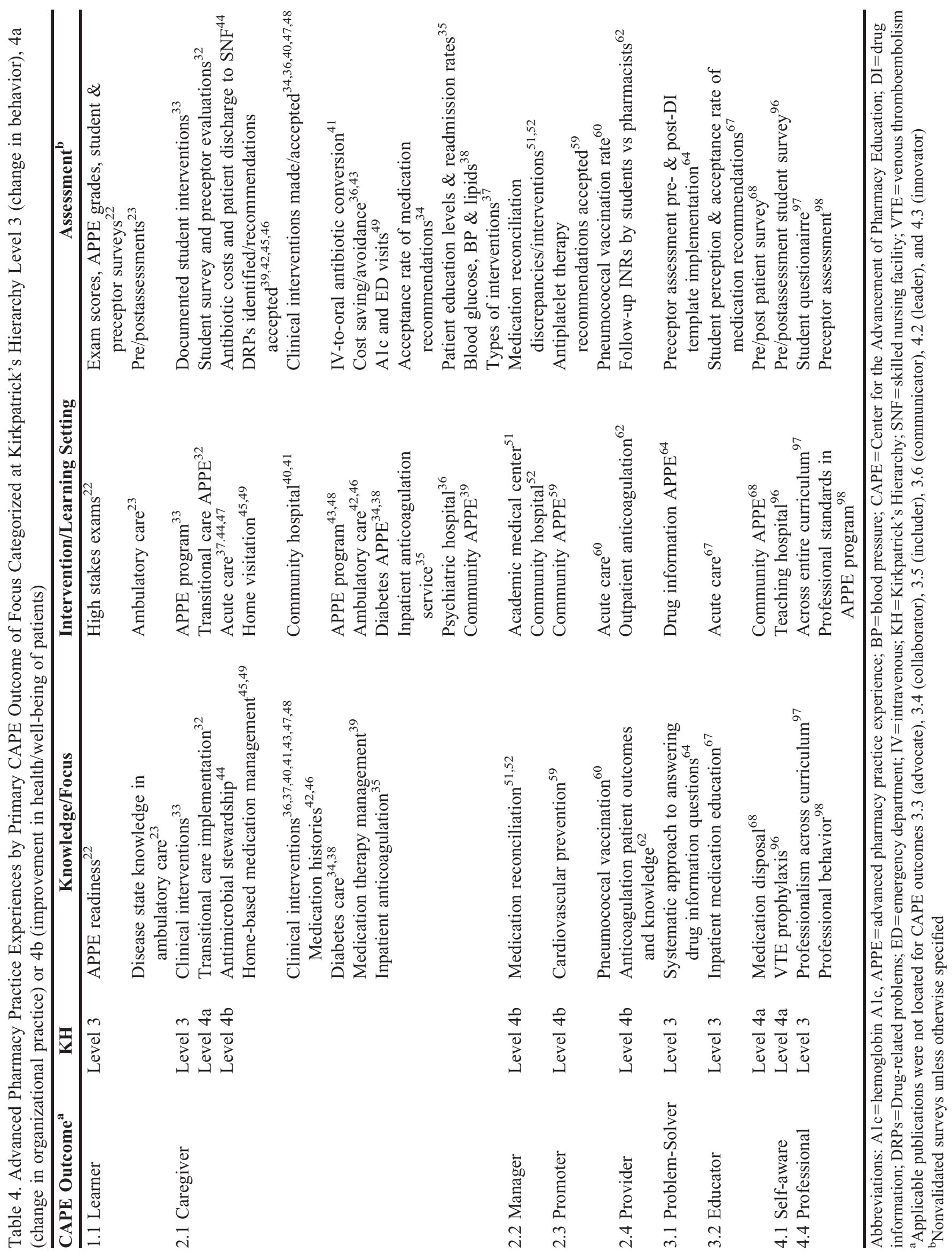




\section{American Journal of Pharmaceutical Education 2016; 80 (7) Article 127.}

Table 5. Categorization of Publications Addressing up to Three CAPE Outcomes for Advanced Pharmacy Practice Experiences

\begin{tabular}{|c|c|c|c|c|}
\hline \multirow[b]{2}{*}{ CAPE Outcome ${ }^{c}$} & \multicolumn{3}{|c|}{ Level of Emphasis } & \multirow[b]{2}{*}{ Total by Outcome $(\%)^{d}$} \\
\hline & Primary & $2^{\text {nd }}$ Level & $3^{\text {rd }}$ Level & \\
\hline 1.1 Learner & $8-23$ & $\begin{array}{c}24,26,27,30,50,57,58 \\
61,63-6,79,88,93\end{array}$ & $33,68,75,80,96$ & $36(18)$ \\
\hline 2.1 Caregiver & $24-49$ & $\begin{array}{c}8,11,14,19,21,54,55 \\
60,62,75,76,89\end{array}$ & $51,52,59,65,67,69$ & $44(21)$ \\
\hline 2.2 Manager & $50-52$ & $36-7,39,41,43,45$ & 35,38 & $11(5)$ \\
\hline 2.3 Promoter & $53-60$ & - & 34 & $9(4)$ \\
\hline 2.4 Provider & $61-2$ & $77,78,92,96$ & $23,58,84$ & $9(4)$ \\
\hline 3.1 Problem solver & $63-4$ & $18,23,28,33$ & $22,89,91,93$ & $10(5)$ \\
\hline 3.2 Educator & $65-8$ & $16,32,34,35,38,40,56$ & 31,62 & $13(6)$ \\
\hline 3.3 Advocate & - & 53,72 & - & $2(1)$ \\
\hline 3.4 Collaborator & 69 & 44 & 28,42 & $4(2)$ \\
\hline 3.5 Includer & $70-3$ & $74,84,95$ & $27,53,77,78,92$ & $12(6)$ \\
\hline 3.6 Communicator & $74-75$ & $\begin{array}{c}9,15,42,49,51,52,59 \\
67,68,80,87,91\end{array}$ & $30,40,45,50,54,63$ & $20(10)$ \\
\hline 4.1 Self-aware & $76-96$ & $22,31,69,73,97,98$ & $24,32,57,61$ & $31(15)$ \\
\hline 4.4 Professional & $97-98$ & 25,81 & 56 & $5(2)$ \\
\hline
\end{tabular}

$\mathrm{CAPE}=$ Center for the Advancement of Pharmacy Education

${ }^{a}$ Articles were coded as addressing 1, 2 or 3 CAPE outcomes according to the review criteria (totals may differ between columns)

${ }^{\mathrm{b}}$ Data displayed as the reference citation number or range

${ }^{\mathrm{c}}$ Applicable publications were not located for CAPE outcomes 4.2 (leader) or 4.3 (innovator)

${ }^{\mathrm{d}}$ Two hundred and six separate CAPE outcomes were coded; total percent is less than 100 because of rounding

include the related CAPE 2013 subdomain of provider (2.4) occurred in 2010 or later (Table 6). These occurrences may be coincidental, but schools and faculty members may (and should) be utilizing changes in ACPE standards as opportunities for investigation and dissemination within the academy. Notably, the CAPE subdomain of interprofessional collaboration (3.4) was minimally addressed in the findings through 2014, yet represents a significant focus for ACPE Standards 3 and 11 in the 2016 iteration. $^{2}$ To a similar degree, the CAPE outcomes of leadership (4.2) and innovation and entrepreneurship (4.3), reports of which are absent from our review, have essentially been incorporated directly into ACPE standards 2016 within Standard 4 (Personal and Professional Development). ${ }^{2}$ These specific CAPE subdomains represent important areas for schools to explore

Table 6. Distribution of CAPE Outcomes Addressed in Advanced Pharmacy Practice Experiences from 1997 to 2014. ${ }^{\mathrm{a}}$

\begin{tabular}{lcccc}
\hline & \multicolumn{3}{c}{ Number of Publications by Year } & \\
\cline { 2 - 4 } CAPE Outcome $^{\mathbf{b}}$ & $\mathbf{1 9 9 7 - 2 0 0 4}$ & $\mathbf{2 0 0 5 - 2 0 0 9}$ & $\mathbf{2 0 1 0 - 2 0 1 4}$ & Total by Outcome (\%) \\
\hline 1.1 Learner & 4 & 13 & 19 & $36(18)$ \\
2.1 Caregiver & 7 & 16 & 21 & $44(21)$ \\
2.2 Manager & 1 & 3 & 7 & $11(5)$ \\
2.3 Promoter & 2 & 5 & 2 & $9(4)$ \\
2.4 Provider & & & 9 & $9(4)$ \\
3.1 Problem solver & 1 & 5 & 5 & $10(5)$ \\
3.2 Educator & & 2 & 8 & $13(6)$ \\
3.3 Advocate & 1 & 1 & 3 & $2(1)$ \\
3.4 Collaborator & 4 & 6 & 5 & $4(2)$ \\
3.5 Includer & & 8 & 8 & $12(6)$ \\
3.6 Communicator & 1 & 2 & 19 & $20(10)$ \\
4.1 Self-aware & & 2 & $31(15)$ \\
4.4 Professional & & & 2 & $5(2)$ \\
\hline
\end{tabular}

$\mathrm{CAPE}=$ Center for the Advancement of Pharmacy Education

${ }^{a}$ Includes coding of CAPE outcomes at any level of emphasis (primary, $2^{\text {nd }}$ and $3^{\text {rd }}$ level); see Table 5

${ }^{\mathrm{b}}$ Applicable publications were not located for CAPE outcomes 4.2 (leader) or 4.3 (innovator)

${ }^{\mathrm{c}}$ Two hundred and six separate CAPE outcomes were coded; total percent is less than 100 because of rounding 


\section{American Journal of Pharmaceutical Education 2016; 80 (7) Article 127.}

and share findings through scholarly publications as encouraged in the ACPE 2016 guidance document. ${ }^{3}$

Equally important to the emphasis on CAPE outcomes addressed by APPEs in published literature is determining the level and quality of assessment applied to the desired learning outcomes and their impact, which was also a purpose of our review. Kirkpatrick's hierarchy provides a framework to stratify assessment methods and impact, from surveys of student satisfaction at the lowest level (1), to student patient care interventions affecting patient care at the highest level (4b). Organizing the CAPE outcome subdomains by various KH levels provides perspective on the range of assessment methods used within and across subdomains, but the level and rigor of assessment methods used varies within each $\mathrm{KH}$ level. For example, within KH level 2 (learning), assessment methods include the use of nonvalidated and validated surveys. These assessment methods are useful for their intended purposes, but are not necessarily meant to be comparable, as they would not be presumed to have the same validity. And while it is generally desirable to have the highest possible impact with our interventions (a benefit to patients), even studies coded at this level could be viewed as having a "surrogate marker" of impact such as clinical interventions accepted vs demonstration of improved patient outcomes. So KH has utility in the organization of publications according to an increasing level of learning "impact," but heterogeneity exists within each level. The validity and reliability of the assessments and results reported are outside the scope of our primary objective; however, Hoover and colleagues' review described areas for general improvement in pharmacy education literature. ${ }^{99}$ Continuously improving scholarly design and quality assessment within pharmacy education is highlighted, and resources are available for consideration when planning and executing experiential education. ${ }^{100-104}$

The authors acknowledge limitations inherent to the Review. While we deployed a broad literature retrieval strategy across several search engines, supplemented the research through table of contents for relevant nonindexed journals, and conducted abstract reviews to identify articles meeting our prespecified criteria, relevant publications may not have been captured. Our objective was to characterize the extent to which published APPE literature addressed current CAPE outcomes, and our results provide a representative aggregate of work meeting our criteria. It is also feasible that our decisions regarding the coding of publications according to the CAPE 2013 outcomes and $\mathrm{KH}$ included degrees of subjectivity. We attempted to minimize arbitrary decisions through two independent reviews of each publication according to prespecified criteria, discussion of discrepancies, and obtaining consensus when necessary for resolution.

Our results provide a basis to reflect on published work of APPE education during a time of significant change in the pharmacy academy. The CAPE outcomes and ACPE standards have been revised three times since 1996, which was the starting point of our literature review. Each iteration has guided schools and faculty members in the contemporary delivery of professional programs and presented opportunities to experiment with curricula, subsequently sharing results through publication. The CAPE 2013 Outcomes are in keeping with a forward-thinking curriculum and have been embraced by the ACPE 2016 Standards, which will guide the academy's focus for the next several years. This review is intended to provide a historic window of how published APPE education is reflected in the CAPE 2013 Outcomes, stimulate inquiry into the improvement of assessment quality, and determine new methods to address outcomes of emerging importance to the profession and society.

\section{CONCLUSION}

Faculty members and preceptors report pharmacy student contributions and learning for the majority of the current CAPE 2013 outcomes. Outcomes related to caregiver (2.1), learner (1.1), self-aware (4.1), communicator (3.6), and educator (3.2) are frequently addressed in APPE reports, while achievement of newer outcomes such as leadership (4.2) and innovation and entrepreneurship (4.3) are notably absent. The level of assessment according to Kirkpatrick's Hierarchy shows a wide distribution, from qualitative survey methods to change in behavior and improvement in the health/well-being of patients. Scholarly design and quality of assessment methods used in APPEs are areas for continued improvement.

\section{ACKNOWLEDGMENTS}

No funding was provided to support this research. Authors do not have any conflicts of interest to report.

\section{REFERENCES}

1. Medina MS, Plaza CM, Stowe CD, et al. Center for the Advancement of Pharmacy Education 2013 educational outcomes. Am J Pharm Educ. 2013;77(8):Article 162.

2. Accreditation Council for Pharmacy Education. Accreditation standards and key elements for the professional program in pharmacy leading to the doctor of pharmacy degree (Standards 2016). Approved January 25, 2015. http://www.acpe-accredit.org/pdf/ Standards2016FINAL.pdf. Accessed July 2, 2015.

3. Accreditation Council for Pharmacy Education. Guidance for the accreditation standards and key elements for the professional program in pharmacy leading to the doctor of pharmacy degree (Guidance for Standards 2016). Approved January 25, 2015. https:// 


\section{American Journal of Pharmaceutical Education 2016; 80 (7) Article 127.}

www.acpe-accredit.org/pdf/GuidanceforStandards2016FINAL.pdf. Accessed July 2, 2015.

4. Yardley S, Dornan T. Kirkpatrick's levels and education 'evidence.' Med Educ. 2012;46(1):97-106.

5. Best Evidence Medical Collaboration (BEME) Collaboration. BEME Coding Sheet - BEME Collaboration. 2012. http://www. bemecollaboration.org/downloads/749/beme4_appx1.pdf. Accessed July 2, 2015

6. Salter SM, Karia A, Sanfilippo FM, Clifford RM. Effectiveness of e-learning in pharmacy education. Am J Pharm Educ. 2014;78(4): Article 83.

7. Poirier T, Behnen E. Where and how to search for evidence in the education literature: the WHEEL. Am J Pharm Educ. 2014;78(4): Article 70.

8. Bookstaver PB, Rudisill CN, Bickley AR, et al. An evidencebased medicine elective course to improve student performance in advanced pharmacy practice experiences. Am J Pharm Educ. 2011;75 (1): Article 9.

9. Arif SA, Gim S, Nogid A, Shah B. Journal clubs during advanced pharmacy practice experiences to teach literature-evaluation skills. Am J Pharm Educ. 2012;76(5):Article 88.

10. Blommel ML, Abate MA. A rubric to assess critical literature evaluation skills. Am J Pharm Educ 2007;71(4):Article 63.

11. Hogan S, Lundquist LM. The impact of problem-based learning on students' perceptions of preparedness for advanced pharmacy practice experiences. Am J Pharm Educ. 2006;70(4):Article 82. 12. Howard PA, Grauer DW. Attitudes of PharmD students toward web-based versus paper-based case studies on a cardiology clerkship. Am J Pharm Educ. 2004;68(1):Article 2.

13. Ellis SL, Nuffer W, Turner CJ. Diabetes-focused rotation's impact on student confidence and knowledge. Curr Pharm Teach Learn. 2012;4(3):174-179.

14. Thomas SG, Hester EK, Duncan-Hewitt W, Villaume WA. A high-stakes assessment approach to applied pharmacokinetics instruction. Am J Pharm Educ. 2008;72(6):Article 146.

15. Abate MA, Blommel ML. Self-assessment tool for drug information advanced pharmacy practice experience. Am J Pharm Educ. 2007;71(2):Article 2.

16. Flowers SK, Vanderbush RE, Hastings JK, West D. Web-based multimedia vignettes in advanced community pharmacy practice experiences. Am J Pharm Educ. 2010;74(3):Article 39.

17. Barclay SM, Jeffres MN, Bhakta R. Educational card games to teach pharmacotherapeutics in an advanced pharmacy practice experience. Am J Pharm Educ. 2011;75(2):Article 33. 18. Al-Dahir S, Bryant K, Kennedy KB, Robinson DS. Online virtual-patient cases versus traditional problem-based learning in advanced pharmacy practice experiences. Am J Pharm Educ. 2014;78 (4): Article 76.

19. Chisholm MA. A renal transplantation advanced pharmacy practice experience. Am J Pharm Educ. 2006;70(1):Article 3. 20. Dennis VC, Britton ML, Wheeler RE, Carter SM. Practice experiences at a single institutional practice site to improve advanced pharmacy practice examination performance. Am J Pharm Educ. 2014;78(3):Article 60.

21. McClendon KS, Malinowski SS, Pitcock JJ, et al. A multipreceptor approach to ambulatory care topic discussion. Am J Pharm Educ. 2014;78(4):Article 77.

22. Meszaros K, Barnett MJ, McDonald K, et al. Progress examination for assessing students' readiness for advanced pharmacy practice experiences. Am J Pharm Educ. 2009;73(6):Article 109.
23. Masters KP, Havrda DE, Johnson G, Spray J. Assessing student knowledge using pre-and postrotation testing on an ambulatory care advance pharmacy practice experience and the use of interactive disease state discussions. Curr Pharm Teach Learn. 2012; 4(2):122-131.

24. McDuffie CH, Sheffield MC, Miller MS, Duke LJ, Rogers SP. Web-based portfolios for pharmaceutical care plans during advanced pharmacy practice experiences. Am J Pharm Educ. 2010;74(4): Article 59.

25. Stevenson TL, Hornsby LB, Phillippe HM, Kelley K, McDonough S. A quality improvement course review of advanced pharmacy practice experiences. Am J Pharm Educ. 2011;75(6): Article 116.

26. Condren M. Diabetes camp as an experiential clerkship site. Am J Pharm Educ. 2003;67(4):Article 119.

27. Johnson JF. A diabetes camp as the service-learning capstone experience in a diabetes concentration. Am J Pharm Educ. 2007;71 (6):Article 119.

28. Petrie JL. Integration of pharmacy students within a level II trauma center. Am J Pharm Educ. 2011;75(6):Article 121.

29. Seifert CF, Veronin M, Kretschmer TD, et al. The training of a telepharmacist: addressing the needs of rural West Texas. Am J Pharm Educ. 2004;68(3):Article 60.

30. Mort JR, Johnson TJ, Hedge DD. Impact of an introductory pharmacy practice experience on students' performance in an advanced practice experience. Am J Pharm Educ. 2010;74(1): Article 11.

31. Packard KA, Lenz TL, Destache CJ. Teaching heart failure treatment guidelines and assessing heart failure therapy. Am J Pharm Educ. 2010;74(6):Article 103.

32. Walker PC, Tucker Jones JN, Mason NA. An advanced pharmacy practice experience in transitional care. Am J Pharm Educ. 2010;74(2):Article 20.

33. Divall MV, Zikaras B, Copeland D, Gonyeau M. School-wide clinical intervention system to document pharmacy students' impact on patient care. Am J Pharm Educ. 2010;74(1):Article 14.

34. McCollum M, Nuffer W, Ellis SL, Turner CJ. Physician acceptance of pharmacotherapy recommendations made by pharmacy students in a rural pharmacy-based diabetes care and education clinic. Am J Pharm Educ. 2009;73(2):Article 24. 35. Wilhelm SM, Petrovitch EA. Implementation of an inpatient anticoagulation teaching service: expanding the role of pharmacy students and residents in patient education. Am J Health Syst Pharm 2011;68(21):2086-2093.

36. Campbell AR, Nelson LA, Elliott E, Hieber R, Sommi RW. Analysis of cost avoidance from pharmacy students' clinical interventions at a psychiatric hospital. Am J Pharm Educ. 2011;75(1): Article 8.

37. Pastakia SD, Vincent WR, Manji I, Kamau E, Schellhase EM. Clinical pharmacy consultations provided by American and Kenyan pharmacy students during an acute care advanced pharmacy practice experience. Am J Pharm Educ. 2011;75(3):Article 42.

38. Nuffer W, McCollum M, Ellis SL, Turner CJ. Further development of pharmacy student-facilitated diabetes management clinics. Am J Pharm Educ. 2012;76(3):Article 50.

39. Hata M, Klotz R, Sylvies R, et al. Medication therapy management services provided by student pharmacists. Am J Pharm Educ. 2012;76(3):Article 51.

40. Shogbon AO, Lundquist LM. Student pharmacists' clinical interventions in advanced pharmacy practice experience at 


\section{American Journal of Pharmaceutical Education 2016; 80 (7) Article 127.}

a community nonteaching hospital. Am J Pharm Educ. 2014;78(3): Article 50.

41. Bock LM, Duong MT, Williams JS. Enhancing clinical services by using pharmacy students during advanced experiential rotations. Am J Health Syst Pharm. 2008;65(6):566-569.

42. Armor BL, Bulkley CF, Truong T, Carter SM. Assessing student pharmacists' ability to identify drug-related problems in patients within a patient-centered medical home. Am J Pharm Educ. 2014;78(1):Article 6.

43. Shepler BM. Cost savings associated with pharmacy student interventions during APPEs. Am J Pharm Educ. 2014;78(4):

Article 71.

44. Benson JM. Incorporating pharmacy student activities into an antimicrobial stewardship program in a long-term acute care hospital. Am J Health Syst Pharm 2014;71(3):227-230.

45. Triller DM. Medication management model as experiential education tool for students of pharmacy. Home Health Care Serv $Q$. 2005;24(1-2):47-59.

46. Fit KE. Documentation of student pharmacists' interventions from medication histories in a primary care setting. J Pharm Technol. 2008;24(6):330-335.

47. Dennehy CE, Kroon LA, Byrne M, Koda-Kimble MA. Increase in number and diversity of clinical interventions by PharmD students over a clerkship rotation. Am J Pharm Educ. 1998;62(4):373-379.

48. Reddick JB, Murphy JE. Evaluating the clinical interventions of students during clerkships using a cognitive services claim form. $\mathrm{Am}$ J Pharm Educ. 2000;64:38-43.

49. Stroup J, Kane MP, Busch RS, Bakst G, Hamil RA. The diabetes home visitation program. Am J Pharm Educ. 2003;67(3):Article 91. 50. Zgarrick DP, Talluto BA. Development of a community pharmacy management elective rotation. Am J Pharm Educ. 1997;61(1):67-73.

51. Lancaster JW, Grgurich PE. Impact of student pharmacists on the medication reconciliation process in high-risk hospitalized general medicine patients. Am J Pharm Educ. 2014;78(2):Article 34. 52. Lubowski TJ, Cronin LM, Pavelka RW, Briscoe-Dwyer LA, Briceland LL, Hamilton RA. Effectiveness of a medication reconciliation project conducted by PharmD students. Am J Pharm Educ. 2007;71(5):Article 94.

53. Patterson BY. An advanced pharmacy practice experience in public health. Am J Pharm Educ. 2008;72(5):Article 125.

54. Cerulli J, Malone M. Women's health promotion within a community advanced pharmacy practice experience. Am J Pharm Educ. 2008;72(2):Article 25.

55. O'Neil C, Berdine H. Experiential education at a universitybased wellness center. Am J Pharm Educ. 2007;71(3):Article 49. 56. Surratt CK, Desselle SP. The neuroscience behind drugs of abuse: a PharmD service-learning project. Am J Pharm Educ. 2004;68(4):Article 99.

57. Whitley HP. A public health discussion series in an advanced pharmacy practice experience. Am J Pharm Educ. 2010;74(6): Article 101.

58. Garrison GD, Lubowski TJ, Miller SM, Strang AF, Sorum PC, Hamilton RA. Multi-site heart disease risk assessment service provided by pharmacy students. Am J Pharm Educ. 2010;74(3): Article 41.

59. Haggerty SA, Cerulli J, Zeolla MM, Cottrell JS, Weck MB, Faragon JJ. Community pharmacy Target Intervention Program to improve aspirin use in persons with diabetes. $J$ Am Pharm Assoc. 2005;45(1):17-22.
60. Dodds ES, Drew RH, May DB, et al. Impact of a pharmacy student-based inpatient pneumococcal vaccination program. Am J Pharm Educ. 2001;65(3):258-260.

61. Brahm N, Farmer KC. A student practice experience focusing on the intellectually disabled. Curr Pharm Teach Learn. 2010; 2(3):138-143.

62. Dalal K, McCall KL, Fike DS, Horton N, Allen A. Pharmacy students provide care comparable to pharmacists in an outpatient anticoagulation setting. Am J Pharm Educ. 2010;74(8):Article 139. 63. Mort JR, Laible BR, Johnson TJ. Implementing standards 2007 to improve students' preparation for advanced pharmacy practice experiences. Am J Pharm Educ. 2011;75(4):Article 74.

64. Lavsa SM, Corman SL, Verrico MM, Pummer TL. Effect of drug information request templates on pharmacy student compliance with the modified systematic approach to answering drug information questions. Ann Pharmacother. 2009;43(11):1795-1801.

65. Ambrose PJ. An advanced pharmacy practice experience in sports pharmacy. Am J Pharm Educ. 2008;72(1):Article 19.

66. Gonyeau MJ, Trujillo J, DiVall M. Development of progressive oral presentations in a therapeutics course series. Am J Pharm Educ. 2006;70(2):Article 36.

67. Donihi AC, Weber RJ, Sirio CA, Mark SM, Meyer SM. An advanced pharmacy practice experience in inpatient medication education. Am J Pharm Educ. 2009;73(1):Article 11.

68. Abrons J, Vadala T, Miller S, Cerulli J. Encouraging safe medication disposal through student pharmacist intervention. $J \mathrm{Am}$ Pharm Assoc. 2010;50(2):169-173.

69. Vesta KS, Farmer KC, Stipek WJ. Pharmacy students' perspectives on the value of taking call during acute care practice experiences. Am J Pharm Educ. 2005;69(3):Article 48.

70. Haack S. Engaging students with diverse patient populations to improve cultural competence. Am J Pharm Educ. 2008;72(5): Article 124.

71. Cooper LA, Vellurattil RP, Quinones-Boex A. Pharmacy students' perceptions of cultural competence encounters during practice experiences. Am J Pharm Educ. 2014;78(2):Article 31. 72. Crandall SJ, Davis SW, Broseker AE, Hildebrandt C. A longitudinal comparison of pharmacy and medical students' attitudes toward the medically underserved. Am J Pharm Educ. 2008;72(6): Article 148.

73. Chen JT, LaLopa J, Dang DK. Impact of patient empathy modeling on pharmacy students caring for the underserved. Am J Pharm Educ. 2008;72(2):Article 40.

74. Mobley-Smith M, Koronkowski MJ, Petersen NM. Enhancing student learning through integrating community-based geriatric educational outreach into ambulatory care advanced practice experiential training. Am J Pharm Educ. 2004;68(1):Article 20. 75. Weathermon RA, Erbele S, Mattson M. Use of standardized patients as an assessment tool at the end of an ambulatory care rotation. Am J Pharm Educ. 2000;64(2):109-113.

76. Briceland LL, Hamilton RA. Electronic reflective student portfolios to demonstrate achievement of ability-based outcomes durings advanced pharmacy practice experiences. Am J Pharm Educ. 2010;74(5):Article 79.

77. Chen JT, Darbishire PL, Plake KS. Assessing student perceptions of the underserved at a Federally Qualified Health Center. Curr Pharm Teach Learn. 2010;2(4):248-254.

78. Tomlin CR, Miller ML, Schellhase E, New G, Karwa R, Ouma MN. Assessing reverse culture shock following an international pharmacy practice experience. Curr Pharm Teach Learn. 2014;6(1):106-113. 


\section{American Journal of Pharmaceutical Education 2016; 80 (7) Article 127.}

79. Wuller CA. A capstone advanced pharmacy practice experience in research. Am J Pharm Educ. 2010;74(10):Article 180. 80. Miller AD, Bookstaver PB, Norris LB. Use of Wikis in advanced pharmacy practice experiences. Am J Pharm Educ. 2009;73(8): Article 139.

81. Smith L, Greene J, Meade L, Spencer B. Qualitative analysis of students' attitudes of duration of community pharmacy practice experiences. Curr Pharm Teach Learn. 2009;1(2):110-114. 82. Nykamp D, Miller SW. Pharmacy student and preceptor perceptions for the first advanced pharmacy practice experience. Curr Pharm Teach Learn. 2011;3(1):9-16.

83. Foote EF, Roland BE, Gionfriddo MR, Holt-Macey S. Differences between residency- and non-residency-trained preceptors on student perceptions and activities of community practice advanced pharmacy practice experiences (APPEs). Curr Pharm Teach Learn. 2014;6(2):259-264.

84. Wietholter JP, Coetzee R, McCartney J, Gegg J, Schwinghammer TL. Development of an international advanced pharmacy practice experience (APPE) and lessons learned after implementation. Curr Pharm Teach Learn. 2014;6(2):304-312.

85. Roche VF, Limpach AL. A collaborative and reflective academic advanced pharmacy practice experience. Am J Pharm Educ. 2011;75(6):Article 120.

86. Rubin RF, Turner T. Student performance on and attitudes toward peer assessments on advanced pharmacy practice experience assignments. Curr Pharm Teach Learn. 2012;4(2):113-122.

87. Miesner AR, Grady S, Trewet CB. Use of student pharmacist peer feedback during a journal club in an advanced in pharmacy practice experience. Curr Pharm Teach Learn. 2012;4(3):165-173. 88. Kirwin JL, Van Amburgh JA, Napoli KM. Service-learning at a camp for children with asthma as part of an advanced pharmacy practice experience. Am J Pharm Educ. 2005;69(3):Article 49. 89. Sylvester RK, Roberg J, Roden W, Smithson K. A hospice-based advanced pharmacy experience. Am J Pharm Educ. 2009;73(3): Article 44.

90. Huynh D, Haines ST, Plaza CM, et al. The impact of advanced pharmacy practice experiences on students' readiness for selfdirected learning. Am J Pharm Educ. 2009;73(4):Article 65. 91. Nystrom KK, Foral PA, Davis EM, Christensen CM, Destache CJ. Rotation students' perceptions of clinical workload documentation using a personal digital assistant. Hosp Pharm. 2009;44(11):968-973.
92. Thomason AR, Elmore LK, Naro PB, Huddleston TW. Pharmacy students' attitudes toward the underserved population: the role of experiential education. Curr Pharm Teach Learn. 2013;5(5):444-449. 93. Lapidus M, Kostka-Rokosz MD, Dvorkin-Camiel L. Librarianlead tutorial for enhancement of pharmacy students' informationsearching skills in advanced experiential rotations. Med Ref Serv $Q$. 2009;28(4):351-362.

94. Marrone CM, Ruble GC. Change in student perception after a pharmaceutical industry advanced pharmacy practice experience. Drug Inf J. 2010;44(2):131-136.

95. Sauer BL. Student-directed learning in a community geriatrics advanced pharmacy practice experience. Am J Pharm Educ. 2006;70(3):Article 54.

96. Butkievich LE, Stacy ZA, Daly MW, Huey WY, Taylor CT. Impact of a student-supported pharmacy assessment program on venous thromboembolism prophylaxis rates in hospitalized patients. Am J Pharm Educ. 2010;74(6):Article 105.

97. Poirier TI, Gupchup GV. Assessment of pharmacy student professionalism across a curriculum. Am J Pharm Educ. 2010;74(4): Article 62.

98. Boyle CJ, Beardsley RS, Morgan JA, Rodriguez de Bittner M. Professionalism: a determining factor in experiential learning. $\mathrm{Am}$ $J$ Pharm Educ. 2007;71(2):Article 31.

99. Hoover MJ, Jung R, Jacobs, DM, Peeters MJ. Educational testing validity and reliability in pharmacy and medical education literature. Am J Pharm Educ. 2013;77(10):Article 213.

100. Medina MS, Bouldin AS, Gonyeau M, et al. Report of the 20112012 Academic Affairs Standing Committee: the evolving role of scholarly teaching in teaching excellence for current and future faculty. Am J Pharm Educ. 2012;76(6):Article S5.

101. Bloodworth LS, Haines SL, Kearney KR, et al. Considerations for embracing and expanding community engaged scholarship in academic pharmacy. Report of the 2013-2014 Research and Graduate Affairs Committee. Am J Pharm Educ. 2014;78(8):Article S8.

102. Anderson HM, Anaya G, Bird E, Moore DL. A review of educational assessment. Am J Pharm Educ. 2005;69(1):Article 12. 103. Peeters MJ, Beltyukova SA, Martin BA. Educational testing and validity of conclusions in the scholarship of teaching and learning. Am J Pharm Educ. 2013;77(9):Article 186.

104. McLaughlin JE, Dean MJ, Mumper RJ, Blouin RA, Roth MT. A roadmap for educational research in pharmacy. Am J Pharm Educ. 2013;77(10):Article 218. 


\section{American Journal of Pharmaceutical Education 2016; 80 (7) Article 127.}

Appendix 1. Kirkpatrick's Hierarchy (KH) Levels and Selected Examples of Representative Assessment Evidence

\begin{tabular}{|c|c|c|}
\hline KH & Description $^{a}$ & Assessment Examples \\
\hline $\begin{array}{l}\text { Level } 1 \\
\quad(\text { reaction })^{\mathrm{b}}\end{array}$ & $\begin{array}{l}\text { Participation: covers learners' views on the } \\
\text { learning experience, its organization, } \\
\text { presentation, content, teaching methods, and } \\
\text { aspects of the instructional organization, } \\
\text { materials, quality of instruction }\end{array}$ & $\begin{array}{l}\text { Survey of student satisfaction with the learning } \\
\text { experience } \\
\text { Student self-assessment of learning or abilities } \\
\text { after a learning experience }\end{array}$ \\
\hline $\begin{array}{l}\text { Level 2a } \\
\quad \text { (learning) }\end{array}$ & $\begin{array}{l}\text { Modification of attitudes/perceptions: outcomes } \\
\text { relate to changes in the reciprocal attitudes or } \\
\text { perceptions between participant groups towards } \\
\text { intervention/simulation }\end{array}$ & $\begin{array}{l}\text { Survey showing a change in: } \\
\text { student self-assessment of learning or abilities } \\
\text { after a learning experience; } \\
\text { student perceptions or attitudes after a learning } \\
\text { experience; } \\
\text { preceptor perception of student abilities after a } \\
\quad \text { learning experience }\end{array}$ \\
\hline $\begin{array}{l}\text { Level } 2 \mathrm{~b} \\
\quad \text { (learning) }\end{array}$ & $\begin{array}{l}\text { Modification of knowledge/skills: for knowledge, } \\
\text { this relates to the acquisition of concepts, } \\
\text { procedures and principles; for skills this relates } \\
\text { to the acquisition of thinking/problem-solving, } \\
\text { psychomotor and social skills }\end{array}$ & $\begin{array}{l}\text { Quantitative change/improvement or } \\
\text { documentation of change in knowledge or skill } \\
\text { as assessed by preceptor, quiz, examination, } \\
\text { performance-based assessment, etc, based on the } \\
\text { primary educational intervention }\end{array}$ \\
\hline $\begin{array}{l}\text { Level } 3 \\
\quad \text { (behavior) }^{\mathrm{b}}\end{array}$ & $\begin{array}{l}\text { Behavioral change: documents the transfer of } \\
\text { learning to the workplace or willingness of } \\
\text { learners to apply new knowledge and skills }\end{array}$ & $\begin{array}{l}\text { Quantitative change/improvement or } \\
\text { documentation of performance in a new } \\
\text { environment based on a previous educational } \\
\text { intervention } \\
\text { Quantitative evidence that learners have } \\
\text { independently improved their application of new } \\
\text { knowledge and skills }\end{array}$ \\
\hline $\begin{array}{l}\text { Level 4a } \\
\qquad \text { (results) }\end{array}$ & $\begin{array}{l}\text { Change in organizational practice: wider changes } \\
\text { in the organization or delivery of care, } \\
\text { attributable to an educational program }\end{array}$ & $\begin{array}{l}\text { Implementation of new initiatives based on } \\
\text { documented outcomes of an educational } \\
\text { intervention }\end{array}$ \\
\hline $\begin{array}{l}\text { Level } 4 \mathrm{~b} \\
\quad(\text { results) }\end{array}$ & $\begin{array}{l}\text { Benefits to patient/clients: any improvement in } \\
\text { the health and well-being of patients/clients as a } \\
\text { direct result of an educational program }\end{array}$ & $\begin{array}{l}\text { Documented change in health care outcomes } \\
\text { directly attributed to an educational intervention } \\
\text { or initiative }\end{array}$ \\
\hline
\end{tabular}

${ }^{\mathrm{a}}$ Adapted from references 4 and 5

${ }^{\mathrm{b}}$ As described by Salter et $\mathrm{al}^{6}$ 